\title{
EFEKTIVITAS KOMUNIKASI TELEPON SELULER PENJUALAN TOMAT KECAMATAN PANGALENGAN KABUPATEN BANDUNG
}

\author{
Gontom Kifli \\ Balai Pengkajian Teknologi Pertanian Kalimantan Barat \\ Email: keevle354@yahoo.com \\ Budi Guntoro dan Endang Sulastri \\ Fakultas Peternakan Universitas Gadjah Mada
}

\begin{abstract}
The access to information on the selling price of tomatoes by tomato growers is perceived very limited in the pastin Pangalengan District. The appearance of information technology, such as mobile phone, provides opportunities for tomatoes growers to obtain the access to more information, wider, faster and cheaper. The general objective of this research is to identify the behavior of tomato growers' communication and the influence aspects of the use of mobile phones toward the effectiveness of communication in Pangalengan District. The method for this research is explanatory survey research. Two-steps random sampling has been used in this research with selected sample of 165 respondents. The research unit is focused on the tomatoes growers who used mobile phones. The result indicates that the tomato growers in Pangalengan District perceive the use of mobile phones provides benefits to have more options for the selling price of tomatoes. The result of statistical analysis shows that the use of mobile phones among tomato growers and tomato sellers has given significant effect on the effectiveness of communication and increasing the intensity of tomato sales.From this research, it is recommended to provide the information management of the selling price of tomatoes via mobile phones involving Agriculture Information Officer (PIP) which already exist today.
\end{abstract}

Keywords: Mobile phone, Tomato growers, The selling price of tomatoes, Pangalengan District

\begin{abstract}
ABSTRAK
Akses informasi terhadap harga jual tomat oleh petani tomat dirasakan sangat terbatas pada masa lalu di Kecamatan Pangalengan. Munculnya teknologi informasi, seperti telepon seluler, memberikan peluang bagi petani tomat tersebut untuk mendapatkan akses informasi yang lebih banyak, lebih luas, cepat dan murah. Tujuan umum penelitian ini adalah mengidentifikasi perilaku komunikasi petani tomat dan pengaruh aspek pemanfaatan telepon seluler terhadap efektivitas komunikasi petani tomat di Kecamatan Pangalengan. Metode penelitian yang dilakukan adalah metode survey explanatory research. Pengambilan sampel dilakukan dengan Two-stage random sampling dengan jumlah sampel terpilih sebanyak 165 orang responden. Unit penelitian difokuskan pada petani tomat yang menggunakan telepon seluler. Hasil statistik analisis menunjukkan bahwa penggunaan telepon seluler di antara petani tomat dan pedagang tomat telah memberikan dampak yang signifikan terhadap efektivitas komunikasi dan meningkatkan intensitas penjualan tomat. Dari penelitian ini, disarankan adanya pengelolaan informasi harga jual tomat melalui telepon seluler dengan melibatkan Petugas Informasi Pertanian (PIP) yang telah ada saat ini.
\end{abstract}

Kata Kunci: Telepon seluler, Petani tomat, Harga jual tomat, Kecamatan Pangalengan 


\section{PENGANTAR}

Pada saat krisis ekonomi yang melanda Indonesia pada tahun 1998, hampir semua sektor mengalami penurunan pertumbuhan ekonominya, kecuali sektor pertanian yang mampu stabil.Seperti data pada tahun 19971998 memperlihatkan bahwa pada saat krisis, pertumbuhan ekonomi nasional mengalami kontraksi atau negatif sebesar 13,68 persen, sedangkan sektor pertanian tetap tumbuh positif sebesar 0,22 persen (Biro Pusat Statistik, 1999). Kondisi ini membuktikan bahwa sektor pertanian di Indonesia merupakan sektor yang mampu memberikan sumbangan sangat berarti dan konsisten bagi pembangunan nasional. Kondisi tersebut berbanding terbalik dengan kondisi nyata petani umumnya di Indonesia hingga saat ini.

Data menunjukkan bahwa kelompok masyarakat yang bekerja sebagai petani merupakan kelompok terbanyak yang termasuk dalam golongan masyarakat miskin. Jumlah penduduk miskin di Indonesia pada bulan September 2011 tercatat sebanyak 29,89 juta orang, yang terdiri dari 10,94 juta orang adalah masyarakat miskin kota, 2,7 juta orang miskin desa non petani dan 16,25 juta orang adalah miskin desa bekerja sebagai petani. Hal tersebut berarti sebanyak 54,37\% masyarakat miskin di Indonesia adalah bekerja sebagai petani (Badan Pusat Statistik, 2012). Kondisi ini mengindikasikan bahwa masih terdapat permasalahan yang dihadapi petani dalam kehidupan ekonominya bila dibandingkan golongan masyarakat lainnya, seperti masyarakat perkotaan dan masyarakat perdesaan bukan petani. Salah satu kondisi yang menjadi permasalahan tersebut adalah sistem pertanian yang masih bersifat subsisten. Pertanian yang bersifat subsisten adalah sistem bertani di mana tujuan utama dari si petani adalah untuk memenuhi keperluan hidupnya beserta keluarganya. Dalam pandangan mereka, pertanian merupakan sarana untuk memenuhi kebutuhan, sehingga produktivitas tanaman tidak maksimal (Mubyarto, 1991). Kondisi subsisten saat ini, salah satunya dapat dicirikan dengan minimnya akses informasi pertanian bagi petani.

Pada sisi lain, dalam meningkatkan produktivitas dan pendapatan petani dari usaha taninya, secara tidak langsung diperlukan adanya dukungan akses terhadap teknologi (Subejo, 2013). Teknologi tersebut termasuk Teknologi Informasi sebagai salahsatu sumber informasi guna meningkatkan pengetahuan kondisi pasar produk. Teknologi telepon seluler merupakan jenis media komunikasi saat ini yang menjadi alternatif bagi petani dalam mengakses informasi pertanian, termasuk informasi harga jual produk. Data dari Kementerian Komunikasi dan Informatika Republik Indonesia (2010) pada tahun 20072008 menunjukkan kepemilikan perangkat telepon seluler di Indonesia mencapai nilai rasio 1,65, secara umum berarti bahwa setiap orang di Indonesia sedikitnya memiliki satu unit perangkat telepon seluler.Selain hampir meratanya kepemilikan telepon seluler, pendukung utama operasional telepon seluler berupa jaringan pemancar seluler dapat dilihat dengan terdapatnya menara operator telepon seluler, telah tersebar ke daerah perdesaan bahkan pedalaman. Dalam era gobalisasi saat ini, penggunaan Teknologi Informasi (TI) termasuk telepon seluler memiliki peran yang penting di dalam meningkatkan akses terhadap infomasi bagi masyarakat termasuk petani. Beberapa penelitian mengenai penggunaan telepon seluler telah dilakukan (Tabel 1).

Tabel 1

Beberapa Hasil Penelitian Terkait dengan Pemanfaatan Telepon Seluler

\begin{tabular}{lll}
\hline $\begin{array}{c}\text { Nama Peneliti, tahun } \\
\text { penelitian }\end{array}$ & Lokasi penelitian & Hasil dan Kesimpulan penelitian \\
\hline Singh, 2012 & India & $\begin{array}{l}\text { Beberapa provider operator jaringan menyediakan } \\
\text { layanan pada telepon seluler, berupa kondisi cuaca, } \\
\text { pengendalian hama dan teknologi tepat guna. }\end{array}$ \\
\hline
\end{tabular}


Lanjutan Tabel 1

\begin{tabular}{|c|c|c|}
\hline $\begin{array}{l}\text { Nama Peneliti, tahun } \\
\text { penelitian }\end{array}$ & Lokasi penelitian & Hasil dan Kesimpulan penelitian \\
\hline $\begin{array}{l}\text { Asingwire dan } \\
\text { Okello, } 2011\end{array}$ & Uganda & $\begin{array}{l}\text { Pemanfaatan telepon seluler untuk menghubungkan } \\
\text { petani dengan pasar produknya terkendala pada } \\
\text { infrastruktur, sosial budaya, dan ekonomi. }\end{array}$ \\
\hline Salia et al, 2011 & Ghana & $\begin{array}{l}\text { Pemanfaatan telepon seluler oleh nelayan di pasar } \\
\text { ikan dapat memberikan nilai ekonomi dalam } \\
\text { penjualan ikan rusak yang sebelumnya tidak dapat } \\
\text { terjual, menjadi dapat terjual. }\end{array}$ \\
\hline Mulyandari et al, 2010 & Indonesia & $\begin{array}{l}\text { Telepon seluler sebagai salah satu dari bentuk } \\
\text { Teknologi Informasi berpotensi digunakan } \\
\text { sebagai media berbagi (sharing) pengetahuan bagi } \\
\text { penggunanya. }\end{array}$ \\
\hline Budiman, 2009 & Indonesia-Langkat & $\begin{array}{l}\text { Masyarakat sebagian besar menggunakan telepon } \\
\text { seluler untuk mencari informasi } 72,20 \% \text {. }\end{array}$ \\
\hline Hamidin, 2009 & $\begin{array}{l}\text { Indonesia- } \\
\text { Padangsidempuan }\end{array}$ & $\begin{array}{l}\text { Masyarakat merasakan dengan menggunakan } \\
\text { telepon seluler, dapat menambah koneksi/ kenalan } \\
\text { ( } 34 \% \text { responden) dan mendukung pekerjaannya ( } 27 \% \\
\text { responden). }\end{array}$ \\
\hline $\begin{array}{l}\text { Ramburn dan Van } \\
\text { Belle, } 2011\end{array}$ & Afrika Selatan & $\begin{array}{l}\text { Fasilitas telepon seluler yang paling sering digunakan } \\
\text { adalah SMS. Hambatan pengembangan telepon seluler } \\
\text { adalah biaya pulsa per satuan waktu yang cenderung } \\
\text { naik, sedangkan pemilihan menggunakan data (SMS) } \\
\text { disebabkan biaya per paket yang relatif murah. }\end{array}$ \\
\hline $\begin{array}{l}\text { Guenthner dan } \\
\text { Swan, } 2011\end{array}$ & US & $\begin{array}{l}\text { Penggunaan telepon seluler oleh petani kentang } \\
\text { untuk keperluan usaha taninya, ternyata lebih tinggi } \\
\text { dibandingkan para mahasiswa dalam kesehariannya. }\end{array}$ \\
\hline Rashid and Elder, 2009 & $\begin{array}{l}\text { Jamaica, Brasil, } \\
\text { Trinida Tobago, } \\
\text { Peru, Mexico, } \\
\text { Columbia, } \\
\text { Argentina }\end{array}$ & $\begin{array}{l}\text { 1) Golongan masyarakat ekonomi lemah merasa } \\
\text { terbantu dengan adanya telepon seluler dalam } \\
\text { berkomunikasi dengan kerabat atau sahabatnya } \\
\text { yang jauh. } \\
\text { 2) Harga telepon seluler yang murah }(3,2 \%-8 \% \\
\text { dari pendapatan bulanan) telah mendorong } \\
\text { masyarakat membeli telepon seluler. }\end{array}$ \\
\hline Haryati, 2007 & $\begin{array}{l}\text { Bandung, } \\
\text { Indonesia }\end{array}$ & $\begin{array}{l}\text { Kepemilikan telepon seluler merupakan suatu cara } \\
\text { agar diterima di lingkungan yang diinginkannya. }\end{array}$ \\
\hline
\end{tabular}

Hasil penelitian Adiyoga et al. (2004) menunjukkan bahwa tanaman tomat memiliki nilai koefisien variasi harga yang tertinggi dibandingkan kubis dan kentang, yang berarti komoditas tomat memiliki fluktuasi harga yang paling ektsrem dibandingkan kubis dan kentang, sehingga dalam penanganan pemasaran tomat, secara tidak langsung memerlukan informasi yang lebih cepat dibandingkan komoditas lainnya, seperti kubis dan kentang. Kondisi tersebut menjadi potensi dari telepon seluler untuk dimanfaatkan oleh petani tomat dalam penjualan tomatnya dengan memanfaatkan akses beberapa sumber informasi dengan jangkauan yang lebih luas, sehingga menarik dan penting untuk dilakukan penelitian.

Penelitian ini bertujuan, pertama, mengidentifikasi perilaku komunikasi petani di Kecamatan Pangalengan dalam memanfaatkan telepon seluler pada kegiatan penjualan tomatnya saat ini. Kedua, mengidentifikasi pengaruh intensitas berkomunikasi dengan pedagang perantara, intensitas berkomunikasi 
dengan sesama petani, kualitas informasi yang diakses melalui telepon seluler dan kemampuan berkomunikasi petani melalui telepon seluler terhadap efektivitas komunikasi melalui telepon seluler yang terjadi pada petani tomat di Kecamatan Pangalengan dan tujuan terakhir adalah mengidentifikasi pengaruh efektivitas komunikasi melalui telepon seluler terhadap intensitas penjualan tomat yang terjadi pada petani di Kecamatan Pangalengan.

Penelitian dilakukan dengan metode survei, yaitu penelitian yang mengambil sebagian objek atau orang dari populasi yang ada untuk dijadikan sampel sebagai representasi populasi dan pengambilan data dilakukan dengan kuesioner sebagai alat pengumpul data yang utama. Survei ini bertujuan untuk melakukan penjelasan (explanatory research) hubungan kausal antar variabel-variabel melalui pengujian hipotesis (Singarimbun, 1991). Dalam penelitian ini, populasi adalah petani tomat yang memiliki dan menggunakan telepon seluler di Kecamatan Pangalengan.Penelitian dilakukan dengan menggunakan pendekatan gabungan antara pendekatan kualitatif dan kuantitatif atau dikenal dengan mix-method research. Di dalam pendekatan kuantitatif, data primer dan informasi didapatkan melalui wawancara berstruktur yang berpedoman kepada kuesioner yang telah dibuat. Dalam mendukung data kuantitatif yang didapatkan, dilakukan pengumpulan data secara kualitatif melalui wawancara mendalam, pengamatan langsung terhadap objek penelitian dan catatan dokumen dari informan dan Forum Group Discussion (FGD). Menurut Creswell (1995) pendekatan mixmethod dapatdilakukan secara parallel/ simultaneous study, yaitu peneliti melakukan pengambilan data kuantitatif dan kualitatif secara bersamaan.

Pengambilan sampel dilakukan dengan pengambilan acak sampel dua tahap (Twostage random sampling), yaitu terdiri dari pengambilan acak sampel pertama sebagai pengambilan acak sampel primer, dan tahap kedua adalah pengambilan sampel yang diambil dari sampel primer disebut sebagai sampel sebagai pengambilan sampel sekunder (Rao, 2000). Pengambilan sampel primer dilakukan dengan memilih kelompok petani tomat sebanyak 12 kelompok tani tomat dari 24 kelompok tani tomat yang ada di Kecamatan Pangalengan secara acak, kemudian dari 12 kelompok tani tersebut dipilih secara acak dari masing-masing kelompok tani sebanyak $50 \%$ dari jumlah petani tomat dari setiap kelompok terpilih, sehingga terkumpul keseluruhan sebanyak 165 orang petani tomat. Jumlah petani yang terpilih sebanyak 165 orang tersebut adalah sampel yang menjadi responden di dalam penelitian yang dilaksanakan. Unit penelitian di dalam penelitian ini adalah petani pemilik lahan sekaligus penggarap yang berusaha tani tomat serta memiliki dan menggunakan telepon seluler.

Analisis statistik yang digunakan dalam penelitian ini adalah statistik parametrik dengan menggunakan analisis regresi. Di dalam penggunaan statistik parametrik, beberapa syarat yang perlu dipenuhi dalam penggunaannya; 1 ) jenis data yang digunakan adalah interval atau rasio, 2) distribusi data (populasi) adalah normal atau mendekati normal, 3) data dalam jumlah besar, biasanya diatas 30 sampel (Santoso, 2014). Widiyanto (2013) dan Dajan (2008) menetapkan bahwa, selain ketiga syarat tersebut, hal penting lainnya adalah dilakukannya pemilihan sampel secara acak (random) dari populasinya, sehingga sampel yang diambil dianggap dapat mewakili dan menggambarkan kondisi populasi. Sheskin (2004) menyaratkan data minimal yang digunakan adalah skala interval. Syarat-syarat tersebut telah terpenuhi dalam pengolahan data penelitian.

\section{PEMBAHASAN Karakteristik Wilayah}

Wilayah Kecamatan Pangalengan secara administrasif termasuk ke dalam wilayah Kabupaten Bandung Propinsi Jawa Barat dan berada sekitar $51 \mathrm{Km}$ arah selatan dari Kota Bandung dan $23 \mathrm{Km}$ dari ibukota Kabupaten Bandung, yaitu Soreang. Posisi Kecamatan 
Pangalengan berada pada koordinat bumi 107029'00" BT sampai 107039'00" BT (Gambar $07^{0} 06^{\prime} 00^{\prime \prime}$ LS hingga $07^{0} 19^{\prime} 00^{\prime \prime}$ LS dan 1).

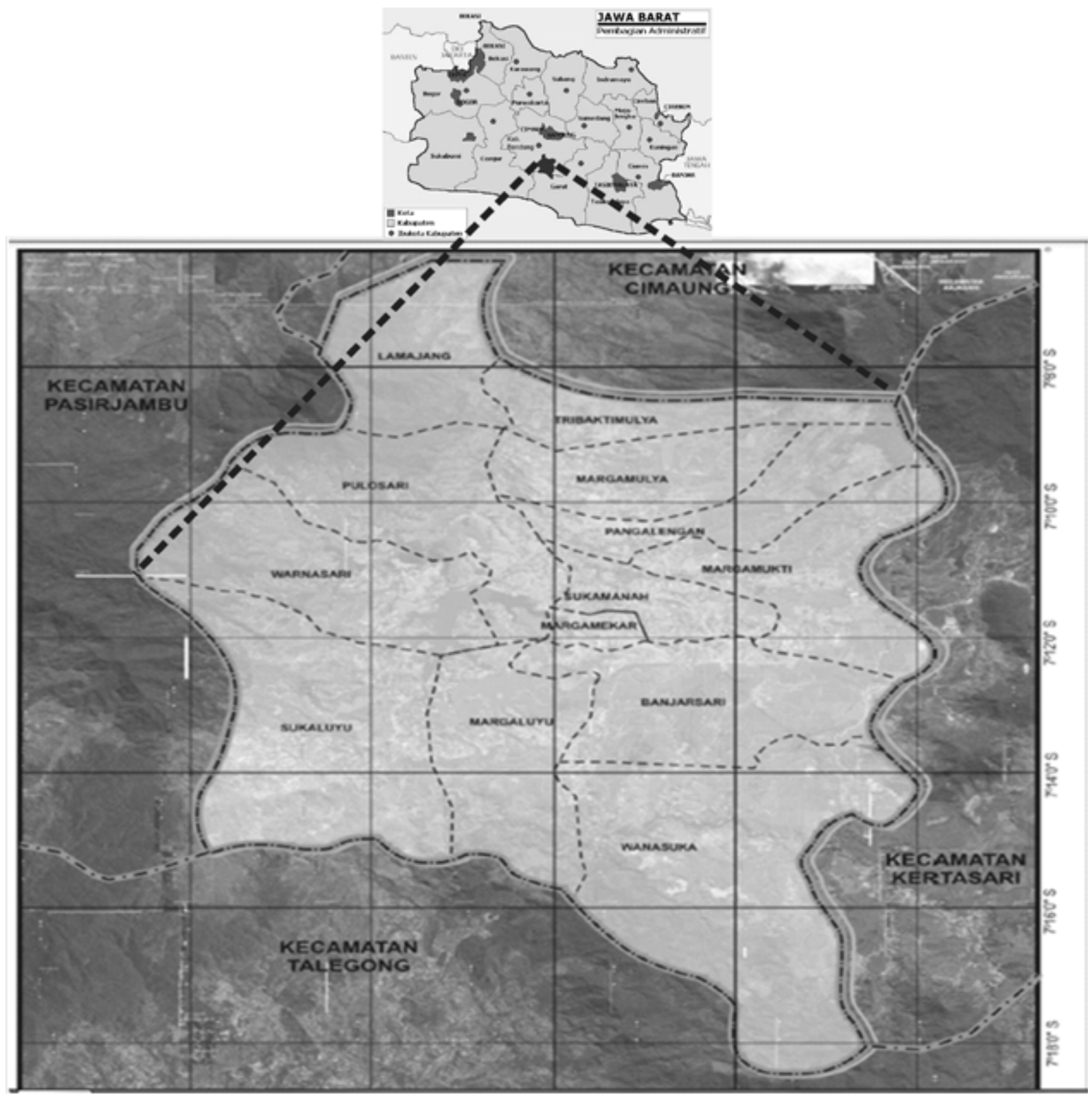

Gambar 1

Peta Kecamatan Pangalengan

(Sumber : Nurfatimah, 2011)

Kecamatan Pangalengan merupakan daerah dataran tinggi dengan kisaran ketinggian wilayah antara 983,89 meter hingga $1.570,94$ meter di atas permukaan laut, dengan ketinggian wilayah tersebut, tanaman yang banyak ditanam dan cocok adalah tanaman sayuran seperti kol, kentang, wortel, brokoli, tomat, cabe dan tanaman sayuran lainnya.
Temperatur lingkungan di Kecamatan Pangalengan berkisar antara $16^{\circ} \mathrm{C}-25^{\circ} \mathrm{C}$ (Badan Pusat Statistik Kabupaten Bandung, 2012). Topografi Kecamatan Pangalengan yang berbukit-bukit umumnya terbagi menjadi 3 (tiga) wilayah, yaitu pemukiman penduduk, kebun sayuran dan perkebunan teh. 
Satu hal yang menarik dari kondisi usaha tani yang terjadi di Kecamatan Pangalengan, yaitu dimanfaatkannya hampir seluruh lahan yang ada. Hal ini dapat terlihat dari ditanaminya wilayah lahan pertanian dengan berbagai macam tanaman, terutama tanaman sayuran, walaupun kebun sayuran tersebut memiliki kemiringan lahan hampir mencapai $45^{0}$ atau $45 \%$.

\section{Karakteristik dan Perilaku Komunikasi Responden}

Kondisi umur responden berada pada kisaran umur 21 tahun hingga 74 tahun dengan rata-rata umur adalah 33 tahun. Dalam pengelompokkan yang dilakukan Badan Pusat Statistik (BPS) terdapat kelompok umur produktif dengan kisaran umur 17 tahun hingga 64 tahun, dan umur non produktif yaitu kisaran umur 0 hingga 16 tahun serta kisaran umur lebih dari 64 tahun. Umur responden apabila bedasarkan kepada pengelompokkan BPS tersebut, maka jumlah kelompok umur produktif responden mencapai 91\% dari seluruh rseponden, sehingga menjadi kelompok umur terbesar atau terbanyak. Pemilihan profesi sebagai petani sayuran oleh para petani muda tersebut dianggap menguntungkan, karena dapat memberikan penghasilan dengan cepat dalam setiap minggunya dengan menjual hasil panen sayurannya. Sistem bertani sayuran secara tumpangsari memungkinkan terjadinya panen tanaman yang berbeda dalam setiap minggunya, sehingga selama masa tanam dan berproduksi, petani dapat memanen sayuran sedikitnya dalam tiap minggu. Para petani muda tersebut lebih memilih menjadi petani sayuran dibandingkan pekerjaan lain, seperti menjadi tukang ojek dan lainnya atau merantau mencari pekerjaan ke luar Pangalengan.

Tingkat pendidikan formal dari sebagian responden adalah tamat Sekolah Dasar atau SD. Kondisi tersebut menurut responden disebabkan pada dua situasi, yang pertama, situasi disebabkan oleh keterbatasan ekonomi keluarganya, sehingga orangtua responden dahulu tidak mampu menyekolahkan responden kepada jenjang pendidikan formal yang lebih tinggi, seperti ke Sekolah Menengah Pertama atau yang lebih tinggi, yang memerlukan banyak biaya yang dikeluarkan selama proses pendidikan berlangsung, seperti iuran bulanan, pakaian seragam, buku pelajaran dan lainnya. Kedua, situasi disebabkan oleh responden umumnya hanya memiliki pendidikan formal hingga SD adalah orang tua responden dahulu lebih memilih meminta anaknya (responden) untuk membantu orangtuanya bekerja di lahan sayurannya dengan pekerjaan tertentu, seperti memanen dan tidak melanjutkan sekolahnya ke jenjang yang lebih tinggi. Hal tersebut dilakukan karena, orang tua merasa terbantu tenaga kerjanya oleh anaknya dengan ikut dalam kegiatan usaha tani sayuran keluarganya. Sementara itu apabila orang tua menyekolahkan anaknya ke tingkat yang lebih tinggi lagi, seperti Sekolah Menengah Pertama (SMP), Sekolah Menengah Atas (SMA) atau perguruan tinggi, berarti akan memerlukan dan mengeluarkan uang yang banyak untuk segala kebutuhan sekolah anaknya tersebut.

Petani tomat responden merupakan petani pemilik lahan dan sekaligus penggarap. Sebagian besar responden memiliki lahan yang cukup luas, yaitu sebesar 372,00 tumbak atau sekitar $5.200 \mathrm{~m}^{2}$ atau 0,52 Hektar perRumah Tangga Petani (RTP). Luasan ratarata tersebut lebih besar dibandingkan dengan luas rata-rata kepemilikan lahan petani di Indonesia yaitu 0,30 Ha per RTP (Direktorat Sarana dan Prasarana Pertanian Kementerian Pertanian, 2013) dan untuk Pulau Jawa tentunya akan lebih kecil dari 0,30 Ha per RTP. Alih fungsi lahan dari lahan sayuran ke fungsi lain, sangat kecil terjadi di Kecamatan Pangalengan, bahkan yang terjadi adalah perluasan lahan usahatani sayuran dari lahan kosong perkebunan teh menjadi lahan usahatani sayuran, dengan sistem persewaan tahunan yang dilakukan oleh petani guna meningkatkan luas panen usahatani tomatnya. Sementara itu, rata-rata luas lahan tomat yang dimiliki responden adalah 237,77 tumbak atau sekitar 3.328,00 
$\mathrm{m}^{2}$ atau 0,33 Ha per RTP. Hal tersebut berarti rata-rata luasan lahan yang digunakan untuk usahatani Tomat adalah sekitar 63,46\% dari rata-rata luas lahan keseluruhan yang dimiliki masing-masing responden, dan ini berarti bahwa lebih dari setengah lahan yang dimiliki responden digunakan untuk berusahatani tomat.

Sebagian besar responden $(96,36 \%)$ memiliki satu unit telepon seluler. Kondisi tersebut sama dengan jumlah kepemilikan telepon seluler per orang di Indonesia saat ini yang dirilis oleh Kementerian Komunikasi dan Informatika (2010) adalah 1,65. Hal tersebut berarti bahwa sedikitnya satu orang di Indonesia memiliki satu unit telepon seluler. Sementara itu, sebagian besar responden memiliki hanya satu unit telepon seluler, tetapi dari kepemilikan satu telepon seluler tersebut, beberapa responden memiliki dua kartu operator yang berbeda atau duos systems. Jenis telepon seluler yang dimiliki oleh hampir seluruh responden $(98.18 \%)$ adalah jenis biasa yang tidak memiliki sistem operasi atau operating systems atau OS.Jenis telepon seluler ini terbatas pada layanan dasar berupa pangilan suara (voice call) dan short messages service (sms) dan tidak dapat mengakses jaringan internet.

Pengeluaran biaya operasional telepon seluler, responden mengeluarkan biaya untuk pembelian pulsa dalam sebulannya sekitar Rp 50.000,00. Penggunaan biaya pulsa rata-rata yang digunakan responden dalam satu minggu adalah sekitar Rp 13.000,00 atau sekitar $\operatorname{Rp} 1.800,00$ dalam satu hari. Pengunaan pulsa tersebut sebagian besar digunakan atau dihabiskan untuk keperluan usaha tani tomat, terutama dalam proses tawar menawar dan kesepakatan hingga penjualan tomat milik responden. Sebagian besar responden membeli dan menggunakan pulsa kurang dari Rp 40.000,00 dalam satu bulan, tetapi biaya pembelian tersebut berada di bawah rata-rata pengeluaran biaya pulsa dari seluruh responden. Responden lainnya, sebanyak 19,39\%, membeli dan menggunakan pulsa yang cukup besar, yaitu antara Rp 100.000,00 hingga Rp 159.000,00. Responden tersebut merasa bahwa mereka memerlukan komunikasi yang intensif atau terus menerus guna mendapatkan informasi yang akurat dan cepat, terutama dalam proses negosiasi dan transaksi harga jual tomatnya hingga terjualnya tomat dengan harga yang dianggap tidak merugikannya. Kondisi tersebut mengakibatkan tingginya biaya penggunaan pulsa oleh responden tersebut.

Responden secara umum melakukan komunikasi melalui telepon seluler dengan rata-rata hampir 4 (empat) orang lain dalam satu hari, dan 2 (dua) orang diantaranya dalam urusannya dengan usaha tani tomatnya. Komunikasi melalui telepon seluler tersebut dilakukan melalui sms dan panggilan suara. Jarak petani dan pedagang yang dihubungi responden melalui telepon seluler adalah jarak fisik/nyata antara kedua belah pihak yang berkomunikasi. Sebagian besar responden berkomunikasi dengan petani tomat lainnya melalui telepon seluler pada jarakrata-rata $30 \mathrm{Km}$ dari tempat tinggalnya. Jarak fisik komunikasi melalui telepon seluler yang dilakukan antara responden sebagai petani tomat dengan pedagang tomat, memiliki rata-rata jarak yang lebih jauh dibandingkan dengan petani tomat lain, dengan rata-rata jarak $65 \mathrm{Km}$ dari tempat tinggalnya. Beberapa lokasi dengan jarak tersebut adalah pasar Pangalengan. Sebagian kecil responden $(4,85 \%$ dari seluruh responden) biasa berkomunikasi dengan pedagang tomat yang berjarak 65 $\mathrm{Km}$ hingga $194 \mathrm{Km}$. Responden tersebut umumnya merupakan petani tomat yang memiliki kenalan dengan pedagang tomat di pasar Kota bandung dan Kota Jakarta, seperti Pasar Induk Caringin Bandung dan Pasar Induk Kramat Jati Jakarta. Situasi tersebut menguntungkan bagi responden tersebut karena harga yang diketahui dari luar Pangalengan dapat dijadikan sumber informasi dan menjadi dasar pertimbangan saat tawar menawar dengan pedagang Pangalengan. 


\section{Hubungan antar variabel}

Di dalam penelitian ini terdapat variabel antara, yaitu variabel efektivitas komunikasi melalui telepon seluler (EFEKTIKOM), yang berada antara variabel aspek pemanfaatan telepon seluler dengan variabel intensitas penjualan tomat. Variabel bebas aspek pemanfaatan telepon seluler terdiri dari intensitas berkomunikasi responden dengan petani tomat lain (INTENSKOMPET), Intensitas berkomunikasi responden dengan pedagang melalui telepon seluler (INTENSPED), Kualitas informasi yang diakses melalui telepon seluler (KUALKOM), dan kemampuan berkomunikasi petani melalui telepon seluler (KEMAMPUKOM). Variabelvariabel tersebut menjadi variabel bebas dan yang menjadi variabel terikat adalah Efektivitas komunikasi melalui telepon seluler (EFEKTIKOM).
Variabel bebas INTENSKOMPET terdiri dari frekuensi berkomunikasi melalui telepon seluler, durasi berkomunikasi melalui telepon seluler dan jumlah petani tomat lain yang diakses melalui telepon seluler. Variabel INTENSPED terdiri dari; frekuensi berkomunikasi melalui telepon seluler, durasi berkomunikasi melalui telepon seluler dan jumlah pedagang tomat lain yang diakses melalui telepon seluler. Variabel KUALKOM terdiri dari ketersediaan informasi, kebaruan informasi, akurasi informasi, relevansi informasi, dan kelengkapan informasi. Variabel KEMAMPUKOM terdiri dari kemampuan menyampaikan pesan, kemampuan memahami pesan, kemampuan menghilangkan gangguan pesan.Variabel terikat EFEKTIKOM terdiri dari tingkat keterbukaan, tingkat empati, pendukungan, tingkat berpikir positif dan tingkat kesejajaran. Hasil analisis statistik regresi linier berganda terdapat pada Tabel 2 .

Tabel 2

Hasil Analisis Statistik Pengaruh Variabel Aspek Pemanfaatan Telepon Seluler terhadap Variabel Efektivitas Komunikasi melalui Telepon Seluler

\begin{tabular}{lllllllll}
\hline \multicolumn{1}{c}{ Model } & \multicolumn{3}{c}{$\begin{array}{c}\text { Unstandardized } \\
\text { Coefficients }\end{array}$} & $\begin{array}{c}\text { Coefficients } \\
\text { Standardized } \\
\text { Coefficients }\end{array}$ & T & Sig. & \multicolumn{2}{c}{$\begin{array}{c}\text { Collinearity } \\
\text { Statistics } \\
\text { Bolerance }\end{array}$ VIF } \\
\hline (Constant) & 49,618 & 8,268 & & 6,001 & 0,000 & & \\
KUALKOM & 0,348 & 0,098 & 0,143 & 3,534 & 0,001 & 0,496 & 2,014 \\
INTENSPED & 0.748 & 0,243 & 0,156 & 3,075 & 0,002 & 0,315 & 3,177 \\
KEMAMPUKOM & 4,661 & 0,377 & 0,681 & 12,372 & 0,000 & 0,269 & 3,722 \\
INTENSKOMPET & 0,126 & 0,199 & 0,023 & 0,633 & $\left.0,527^{*}\right)$ & 0,600 & 1,666 \\
\hline
\end{tabular}

Keterangan : *) non signifikan; Nilai $R=0,933 ; \alpha=0,05$

Dari hasil analisis statistik tersebut, menjadi persamaan regresi linier berganda:

$Y=49,618+0,748 X_{1}+0,126 X_{2}^{*}+0,348 X_{3}+$ $4,661 \mathrm{X}_{4}$

Hasil analisis statistik tersebut mengindikasikan beberapa hal sebagai berikut: Pertama, Nilai R yang merupakan koefesien korelasi ganda, memiliki nilai sebesar 0,933, yang berarti bahwa hubungan antara variabel terikat Efektivitas komunikasi me- lalui telepon seluler dengan keempat variabel bebasnya memiliki korelasi atau hubungan yang sangat kuat. Menurut Santoso (2014), kisaran nilai $\mathrm{R}$ berada antara 0,00 hingga 1,00 , semakin kuat hubungan tersebut, maka nilainya akan mendekati nilai 1,00 dan sebaliknya, nilai $R$ yang mendekati 0,00 menunjukkan hubungan tersebut sangat lemah. Nilai Adjusted $\mathrm{R}^{2}$ bernilai 0,866 berarti bahwa sebesar $86,6 \%$ efektivitas komunikasi telepon seluler dipengaruhi oleh keempat variabel bebas tersebut, sedangkan sisanya 
$(13,4 \%)$ dipengaruhi oleh selain variabelvariabel tersebut.

Kedua, Uji ANOVA atau F test, diketahui F hitung adalah 266,783 dengan tingkat signifikansi 0,000, jauh lebih kecil dari nilai 0,05, yang berarti bahwa model regresi tersebut dapat digunakan untuk memprediksi efektivitas komunikasi melalui telepon seluler dengan variabel-variabel bebasnya, serta variabel-variabel bebas tersebut secara bersama-sama berpengaruh terhadap variabel efektivitas komunikasi. Ketiga, Persamaan regresi :

Efektikom $=49,618+0,748$ intensped + 0,126 intenskompet $+0,348$ kualkom $+4,661$ kemampukom

Konstanta sebesar 49,618 menyatakan bahwa jika tidak ada intensitas komunikasi melalui telepon seluler dengan pedagang tomat dan petani tomat lainnya, kualitas informasi dan kemampaun komunikasi melalui telepon seluler, nilai efektivitas komunikasi melalui telepon seluler adalah sebesar 49,618 poin. Koefisien regresi sebesar 0,748 menyatakan bahwa setiap peningkatan 1 (satu) poin intensitas komunikasi dengan pedagang tomat melalui telepon seluler akan meningkatkan efektivitas sebesar 0,748 poin. Demikian juga peningkatan pada variabel lainnya dengan koefisien regresinya masingmasing.

Keempat, Uji t untuk menguji signifikansi konstanta dan setiap variabel independen, dengan hipotesis:

$\mathrm{H}_{\mathrm{o}}=$ koefisien regresi tidak signifikan

$\mathrm{H}_{1}=$ koefisien regresi signifikan

Pengambilan keputusan, berdasarkan probabilitas,

Jika probabilitas $>0,05$, maka $\mathrm{H}_{\mathrm{o}}$ diterima Jika probabilitas $\leq 0,05$, maka $\mathrm{H}_{\mathrm{o}}$ ditolak Keputusan:
Variabel independen Intensped, Kualkom dan Kemampukom memiliki signifikansi di bawah 0,05 , sehingga ketiga variabel tersebut mempengaruhi variabel Efektikom, sedangkan variabel Intenskompet memiliki signifikansi di atas 0,05, sehingga variabel Intenskompet tidak mempengaruhi (nonsignifikan) variabel terikat Efektikom.

Intensitas komunikasi antara petani tomat dengan petani tomat lainnya tidak berpengaruh terhadap efektivitas komunikasi melalui telepon seluler. Kondisi tersebut disebabkan komunikasi diantara petani tomat belum mencapai efektivitas komunikasi yang dicirikan dengan belum sepenuhnya terjadi keterbukaan, rasa empati, rasa saling mendukung, berpikir positif dan kesejajaran diantara sesamai petani tomat sendiri. Hal tersebut dapat dilihat pada nilai rata-rata intensitas berkomunikasi melalui telepon seluler antara petani tomat dengan pedagang tomat $(61,82 \%)$ yang lebih besar dibandingkan dengan petani tomat lain $(55,15 \%)$, yang berarti bahwa petani (responden) lebih senang berkomunikasi dengan pedagang tomat dibandingkan dengan petani tomat lainnya dalam kaitannya dengan penjualan tomat, terutama mengenai harga jual tomat. Sementara itu, variabel yang berpengaruh paling kuat terhadap efektivitas komunikasi yang terjadi melalui telepon seluler tersebut dilihat dari nilai yang tertinggi hingga terendah, yaitu secara berturut-turut adalah Kemampuan berkomunikasi, Intensitas berkomunikasi melalui telepon seluler dengan pedagang dan kualitas informasi yang didapatkan melalui telepon seluler.

Analisis regresi yang kedua adalah hubungan antara variabel bebas EFEKTIKOM (sebelumnya menjadi variabel terikat) dengan variabel Intensitas penjualan tomat (INTEPJUAL), yang terdiri dari; frekuensi jual beli, kontinuitas ketersediaan informasi dan jumlah pedagang yang bertransaksi. 
Tabel 3

Hasil Analisis Statistik Pengaruh Variabel Efektivitas Komunikasi melalui Telepon Seluler terhadap Variabel Intensitas Penjualan Tomat

\begin{tabular}{|c|c|c|c|c|c|}
\hline \multirow[b]{3}{*}{ Model } & \multicolumn{3}{|c|}{ Coefficients } & \multirow[b]{3}{*}{$t$} & \multirow[b]{3}{*}{ Sig. } \\
\hline & \multicolumn{2}{|c|}{ Unstandardized Coefficients } & \multirow{2}{*}{$\begin{array}{c}\text { Standardized Coefficients } \\
\text { Beta }\end{array}$} & & \\
\hline & B & Std. Error & & & \\
\hline (Constant) & 9.777 & 2.857 & & 3.422 & .001 \\
\hline EFEKTIKOM & .300 & .018 & .799 & 16.962 & .000 \\
\hline
\end{tabular}

Keterangan : nilai $\mathrm{R}=0,799 ; \alpha=0,05$

Dari hasil analisis statistik tersebut, menjadi persamaan regresi linier berganda:

$Y=9,777+0,3 X_{1}$

Persamaan regresi tersebut menunjukkan bahwa:

Hasil analisis statistik regresi linier sederhana pada Tabel 3 menunjukkan beberapa indikasi sebagai berikut:

Pertama, Nilai $\mathrm{R}$ yang merupakan koefesien korelasi ganda, memiliki nilai sebesar 0,799 , yang berarti bahwa hubungan antara variabel bebas efektivitas komunikasi melalui telepon seluler dengan variabel terikat tingkat penjualan tomat yang dilakukan oleh petani tomat memiliki korelasi atau hubungan yang kuat. Nilai Adjusted $\mathrm{R}^{2}$ bernilai 0,636 berarti bahwa sebesar 63,6\% Tingkat penjualan tomat dipengaruhi oleh variabel bebas efektivitas komunikasi melalui telepon seluler, sedangkan sisanya $(36,4 \%)$ dipengaruhi oleh selain variabel-variabel tersebut.

Kedua, Uji ANOVA atau F test, diketahui F hitung adalah 287,714 dengan tingkat signifikansi 0,000 , jauh lebih kecil dari nilai 0,05 , yang berarti bahwa model regresi tersebut dapat digunakan untuk memprediksi Tingkat penjualan tomat dengan menggunakan variabel bebas Efektivitas komunikasi melalui telepon seluler.

Ketiga, Persamaan regresi:Intenpjualn $=9,777+0,30$ Efektkom. Konstanta sebesar 9,777 menyatakan bahwa jika tidak ada atau tidak terjadi efektivitas komunikasi melalui telepon seluler, maka tingkat penjualan tomat adalah tetap sebesar 9,777 poin. Koefisien regresi sebesar 0,30 menyatakan bahwa setiap peningkatan 1 (satu) poin efektivitas komunikasi melalui telepon seluler, akan meningkatkan tingkat penjualan sebesar 0,30 poin. 4) Uji t untuk menguji signifikansi konstanta dan setiap variabel independen, dengan hipotesis: $\mathrm{H}_{\mathrm{o}}=$ koefisien regresi tidak signifikan; $\mathrm{H}_{1}=$ koefisien regresi signifikan. Pengambilan keputusan, berdasarkan probabilitas, Jika probabilitas $>0,05$, maka $\mathrm{H}_{\text {o }}$ diterima. Jika probabilitas $\leq 0,05$, maka $\mathrm{H}_{\mathrm{o}}^{\circ}$ ditolak. Keputusan: Variabel bebas efektivitas komunikasi melalui telepon seluler memiliki signifikansi di bawah 0,05, sehingga variabel tersebut mempengaruhi variabel Tingkat penjualan tomat (Intenpjualn).

Hasil analisis statistik menunjukkan bahwa tingkat penjualan tomat secara nyata dipengaruhi oleh efektivitas komunikasi yang dilakukan melalui telepon seluler oleh petani tomat di Kecamatan Pangalengan. Kondisi tersebut menunjukkan bahwa pada saat ini keberadaan telepon seluler menjadi bagian dari kehidupan bertani dari petani tomat, terutama yang digunakan dalam kaitannya dengan penjualan tomatnya. Sebagian besar penggunaan telepon seluler yang digunakan oleh petani tomat di Kecamatan Pangalengan, yang erat kaitannya dengan bertani tomatnya, digunakan dalam kaitannya dengan penjualan tomatnya, adapun kaitannya dengan usaha tani, ketersediaan sarana produksi pertanian, teknologi bertani tomat dan kaitan lainnya, tidak dilakukan seintensif untuk penjualan tomatnya. Hal tersebut disebabkan petani tomat beranggapan bahwa hal yang terpenting dalam bertani tomatnya adalah penjualan tomatnya, terutama informasi mengenai harga jual tomat yang akan dijualnya. 
Kaitan antara hasil penelitian tersebut dengan teori tersebut adalah terbukti bahwa petani tomat secara terbuka dan sadar bertukar informasi melalui telepon seluler dengan pedagang tomat mengenai penjualan tomatnya, dan kondisi tersebut dipengaruhi secara positif oleh intensitas berkomunikasi, kualitas informasi yang diakses dan kemampuan komunikasi petani tomat. Makna dari fenomena tersebut adalah pertukaran informasi mengenai penjualan tomat yang dialami petani tomat akan semakin baik atau lancar apabila kemampuan komunikasi, intensitas berkomunikasi, kualitas informasi yang diakses yang dilakukan petani tomat melalui telepon seluler semakin baik. Demikian pula selanjutnya bahwa pertukaran informasi melalui telepon seluler yang semakin lancar akan mengakibatkan semakin meningkatnya penjualan tomat petani, yang ditandai dengan frekuensi jual beli yang semakin tinggi, kontinuitas ketersediaan informasi pasa yang tetap terjaga/ada, jumlah pedagang yang bertransaksi semakin banyak dan jangkauan jarak pedagang yang bertransaksi semakin luas.

Beberapa uraian tersebut menunjukkan bahwa hasil penelitian yang dilakukan telah memperkuat teori dasar social exchange theory yang digunakan. Nilai kebaruan (novelty) dari penelitian adalah digunakannya telepon seluler di dalam konteks komunikasi antara pihak petani tomat dan pedagang tomat, sekaligus di dalam penerapan teori dasar yang digunakan. Pada teori social exchange tersebut, konteks pertukaran informasi adalah berlangsung pada komunikasi tatapmuka (face-to face) dan tidak melalui media, sehingga hasil penelitian memberikan pengayaan dari teori tersebut, yaitu bahwa teori social exchange berlaku juga bagi pertukaran informasi yang berlangsung melalui media telepon seluler.

Setelah terbukti bahwa pemenfaatan telepon seluler berpengaruh terhadap aspek penjualan tomat yang dilakukan oleh responden, maka di dalam upaya meningkatkan fungsi dari telepon seluler diperlukan suatu pengelolaan sistem informasi yang mencakup aspek penjualan tomat di Kecamatan Pangalengan, terutama informasi harga. Responden merasakan bahwa pengeluaran biaya rata-rata untuk pembelian pulsanya, masih dianggap mahal dan belum sebanding dengan informasi yang didapatkan serta pendapatan penjualan yang didapatkannya, sehingga diperlukan pengelolaan sistem informasi tersebut, yang dapat menjawab kebutuhan responden terhadap informasi penjualan tomatnya dengan cepat, tepat dan murah. Sistem informasi yang berpotensi untuk dilakukan adalah dengan menggunakan perangkat lunak dan keras komputer yang dapat menerima pesan sms, menyimpan, memilih, menyeleksi, mengelola dan menyebarkan kembali informasi tersebut kepada petani tomat yang mengirim sms tersebut.

Pengelolaan informasi tersebut berpeluang dapat dilakukan oleh pihak manapun, pemerintah, swasta, Lembaga Swadaya Masyarakat (LSM) atau kelompok tani sendiri, mengingat biaya untuk pembelian perangkat tersebut tidak terlalu mahal. Pada saat ini pengelolaan informasi harga sayuran telah dirintis dan dilakukan oleh pihak Dinas Pertanian Propinsi Jawa Barat melalui Petugas Informasi Pasar (PIP), yang salahsatunya berada di Kecamatan Pangalengan. PIP melaporkan harga sayuran di wilayah kerjanya ke pengelola web di Dinas Pertanian Propinsi Jawa Barat, yang selanjutnya diunggah di webnya secara real time. Namun, saat ini informasi tersebut belum dapat diakses oleh sebagian besar petani tomat, karena fasilitas pada telepon seluler yang dimiliki petani belum dapat mengakses web tersebut melalui fasilitas internet, sehingga masih diperlukan pengelolaan sistem informasi yang menggunakan platform sms to web to sms (sms-web-sms).

\section{SIMPULAN}

Beberapa karakteristik dan perilaku komunikasi petani tomat di Kecamatan Pangalengan dalam penjualan tomatnya melalui telepon seluler menunjukan sebagai berikut: Pertama, Setiap petani tomat di 
Kecamatan Pangalengan sedikitnya memiliki satu unit telepon seluler yang dimanfaatkan untuk kepentingan usaha tani tomatnya. Fasilitas utama yang sering digunakan adalah sms dan panggilan suara. Telepon seluler digunakan oleh petani tomat sebagiannya adalah untuk keperluan mendukungpenjualan tomatnya.

Kedua, telepon seluler memberikan keuntungan bagi petani tomat di Kecamatan Pangalengan dalam memperluas jaringan informasi dengan semakin banyaknya orang yang dapat dihubungi, terutama pedagang tomat yang menerima hasil penjualan tomat petani, sehingga petani tomat memiliki lebih banyak pilihan harga jual tomat yang akan dijualnya. Ketiga, Variabel intensitas komunikasi dengan pedagang tomat melalui telepon seluler, kualitas informasi yang didapatkan dan kemampuan berkomunikasi melalui telepon seluler mempengaruhi efektivitas komunikasi melalui telepon seluler oleh petani tomat di Kecamatan Pangalengan, sedangkan intensitas berkomunikasi dengan sesama petani tomat tidak berpengaruh nyata terhadap efektivitas komunikasi melalui telepon seluler. Keempat, Variabel intensitas penjualan tomat sangat dipengaruhi oleh efektivitas komunikasi melalui telepon seluler oleh petani tomat di Kecamatan Pangalengan.

Pemanfaatan dan peningkatan efektivitas komunikasi petani tomat melalui telepon seluler, maka diperlukan pengelolaan informasi yang mengatur informasi antar sesama petani tomat dengan pedagang tomat di Kecamatan Pangalengan, sehingga informasi harga jual tomat dapat lebih terbuka, variatif dan dapat diakses semua petani tomat. Pengelolaan informasi tersebut dapat berupa sistem informasi sms group dengan menggunakan platform sms to web to sms (sms-websms), sehingga dapat diakses dengan mudah dan murah oleh petani maupun pedagang tomat. Pada pelaksanaan di lapangan dapat melibatkan Petugas Informasi Pasar (PIP) di wilayah Kecamatan Pangalengan yang telah ada saat ini.

\section{DAFTAR PUSTAKA}

Adiyoga, W., R. Suherman, T.A. Soetiarso. (2004). Profil Komoditas Tomat. PAATP-Puslitbang Hortikultura, Jakarta. 10-14.

Asingwire, N. dan Okello, J.J. (2011). Challenges Facing Smallholder Farmers' ICT-Based Market Information Service (MIS) Projects: The Case of Brosdi and Wougnet in Uganda. International Journal Economy Research. 2011. Vol. 2(4), Uganda. 1-14.

Badan Pusat Statitik Kabupaten Bandung. (2012). Kabupaten Bandung dalam angka 2011. Badan Pusat Statistik Kabupaten Bandung. Bandung. 45- 47.

Badan Pusat Statistik. (2012). Berita Resmi Statistik No. No. 06/01/Th. XV, 2 Januari 2012. Badan Pusat Statistik, Jakarta. 1-8.

Biro Pusat Statisik. (1999). Statistik Indonesia 1998. Biro Pusat Statistik, Jakarta. 25, 70-72.

Budiman. (2009). Telepon Seluler dan Efektivitas Komunikasi Masyarakat Pedesaan (StudiDiDesa Pertumbukan, Kecamatan Wampu, Kabupaten Langkat). Jurnal Penelitian Komunikasi Dan Pembangunan, Volume 10 No. 1 April 2009. Departemen Komunikasi dan Informatika, Balai Besar Pengkajian dan Pengembangan Komunikasi dan Informatika, Medan. 11-32.

Creswell, J.W. (1995). Research Design: Qualitative and Quantitative Approaches. Thousand Oaks, Sage. California. 208-212.

Dajan, A. (2008). Pengantar Metode Statistik, Jilid I, edisi kesembilan. LP3ES. Jakarta. 202, 214, 219.

Guenthner, J. F. and Swan B. G. (2011). Return To Current Issue; Extension Learners' Use Of Electronic Technology. Journal Of Extension. February 2011, Volume 49 Number 1. 1-9. 
Hamidin, H. (2009). Gaya Hidup Masyarakat Yang Menggunakan Telepon Selular Di Kecamatan Padangsidimpuan Selatan. Jurnal Penelitian Komunikasi dan Pembangunan, Volume 10 No. 2 April 2009. Departemen Komunikasi dan Informatika, Balai Besar Pengkajian dan Pengembangan Komunikasi dan Informatika, Medan. 27-39.

Haryati. (2007). Studi Interaksionisme Simbolik, Budaya Telepon Genggam, Jurnal Penelitian Komunikasi. Balai Pengkajian dan Pengembangan Informasi Wilayah III, Bandung. 91-120.

Kementerian Komunikasi dan Informatika Republik Indonesia. (2010). Komunikasi dan Informatika Indonesia Whitepaper 2010. Kemenkominfo, Jakarta. 30-36.

Mubyarto. (1991). Pengantar Ekonomi Pertanian. LP3ES, Jakarta. 35-40.

Mulyandari, R. S. H., Sumardjo, Pandjaitan, N. K dan Lubis, Dj. P. (2008). Pola Komunikasi Dalam Pengembangan Modal manusia dan Modal Pertanian. Forum Penelitian Agro Ekonomi. Vol. 28 No. 2. Bogor. 135-158.

Ramburn, H. and Van Belle, J. P. (2011). Inhibitors And Enablers Of Mobile Data Services Use In South Africa. Volume 2011 Article Id 710870, Communications Of The IBIMA (Journal). 1-11.

Rao, P.S.R.S. (2000). Sampling Methodologies with Applications. Chapman and Hall/CRC. Florida. 216.

Rashid, A.T and L. Elder. (2009). Mobile Phones And Development: An Analysis Of IDRC-Supported Projects. The
Electronic Journal On Information Systems In Developing Countries. USA. 1-16.

Santoso, S. (2014). Statistik Parametrik, konsep dan aplikasi dengan SPSS. PT. Elex Media Komputindo. Jakarta. 149-152.

Sey, A. (2011). 'We use it different, different': Making sense of trends in mobile phone use in Ghana. new media \& society, 13(3) 375-390. Sage Publication, USA. 375-390.

Salia, M., N. N. N. Nuamah dan W.F. Steel. (2011). Effects Of Mobile Phone Use On Artisanal Fishing Market Efficiency And Livelihoods In Ghana. The Electronic Journal On Information Systems In Developing Countries. 47, 6. 1-26.

Sheskin, D.J. (2004). Handbook of Parametric and Nonparametric Statistical Procedures, third edition. Chapman and Hall/ CRC. Florida. 116.

Singarimbun, M. (1991). Metode Penelitian Survei. Singarimbun, M. dan Effendi, S.. Jakarta: LP3ES.

Singh, A.K. (2012). Mobile Tech Enriching Knowledge Empowering Farmers, Workshop on mobile technology for food secruity, agriculture and rural development, April2012. Bangkok. 1-17.

Subejo. (2013). Bunga Rampai Pembangunan Pertanian dan Pedesaan; Rural Development and Improvement of Rural Life. Cetakan Pertama. UI-Press, Jakarta. 139.

Widiyanto, M. A. (2013). Statistika Terapan, Jakarta: PT. Elex Media Komputindo. 37, 125-134. 